\title{
Validity of computed tomography maxillary sinuses dimensions measuring in sex determination in Egyptian sample
}

\author{
Hadhoud RM, Abdelhakim $\mathbf{E}^{1}$
}

${ }^{1}$ Department of Forensic Medicine and Clinical Toxicology, Faculty of Medicine-Ain Shams University, Cairo Egypt.

\begin{abstract}
Background: Gender determination is an essential issue in forensic medicine. It is one of the deceased person identification data that could not be easily elucidated in several conditions as road traffics and mass disasters. Maxillary sinus is characterized by being intact even with skull disfigurement. Aim of the study: assessment of the maxillary sinus dimensions as measured from CT scan and evaluation of its potential efficacy in sex determination. Patients and methods: 64 patients attended the radiology department Al-Demerdash hospital, Ain Shams University for paranasal sinuses computerized tomography (PNS CT scan) were the subjects of the study. CT scan was performed and maxillary sinus dimensions were obtained. Results: no statistically significant difference was found between both genders regarding the maxillary sinus dimensions. Conclusion: The current study did not validate the use of maxillary sinus dimensions in sex determination among Egyptian individuals.
\end{abstract}

Received in original form: 25 September 2021 Accepted in a final form: 25 December 2021

Key words Maxillary sinuses, person identification, gender determination.

\section{Introduction}

he uniqueness of anatomical structures is the

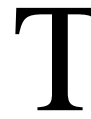
Tbase on which forensic determination of unknown deceased individuals largely depends. This issue is essential in variable situations as road accidents and mass disasters, and as an important tool for investigation of criminal cases. Identification can be performed by several methods, such as fingerprinting, DNA analysis and anthropological methods (Patil et al., 2012).

The use of remained skeleton for investigating an individual identity is a complex process and need continuous efforts and researches to validate the available used tools (Akhlaghi et al., 2017). First of all, it is mandatory to use the still intact bones which resisted crushing and disfigurement. Among them are the maxillary sinuses which persist intact in most critical damaging conditions even with skull disfigurement (Sheikh et al., 2018).

The maxillary sinuses are pyramidal structures situated within the maxilla, they are the largest paranasal sinuses and the first to develop as they develop intrauterine at the $10^{\text {th }}$ week. They drain at the middle nasal meatus of the nasal cavity. After birth they continue to enlarge till the completion of teeth eruption by the third molars. They show variation in size, position and shape among different individuals. Therefore, maxillary sinus could be a tool for gender determination (Bangi et al., 2017).

At the present, Multidetector Computed Tomography (MDCT) has been evolved, with thin sections as well as three-dimensional reconstructions, enabling detailed anatomical evaluation and allowing for accurate assessment of body parts generally and maxillary sinuses specifically. Moreover, PACS (picture archiving and communication system) era applications are allowing proper morphometric analysis dedicatedly of the scan images (Amin et al., 2012).

\section{Aim of the Study}

The present study aimed to assess the sinus dimensions as measured from CT scan and evaluate its potential efficacy in sex determination.

\section{Patients and Methods}

Study design: this is a descriptive cross-sectional study. Study setting: Radiology department, Al-Demerdash hospital, Ain Shams University.

Sample size and characteristics: Egyptian adult patients who had been referred to radiology department in the period from September 2019 to September 2020, with CT PNS request and were aged above 20 were included in this study. Patients with any maxillary sinus congenital abnormality or with disintegrates implicating their maxillary sinuses bony walls, as fracture or aggressive invasive process were excluded from the study.

Ethical considerations: A written consent was obtained from every patient and the study was conducted according to the institutional ethical committee approval.

Methods: Paranasal sinuses axial and coronal CT scanning examinations were performed with the patient 
in the prone position by the radiology technician. We obtained the included patients' examinations from the department PACS system.

The following were measured:

- Maximum height (distance from the upper to the lower sinus borders in the largest sinus coronal section) (figure 1)

- Maximum width (distance from the medial to the lateral sinus borders in the largest sinus coronal section) of both right and left maxillary sinuses (figure 1)

Maximum anterior- posterior diameter (distance from the anterior to the posterior sinus borders in the largest sinus axial section) (figure 2).

Statistical analysis

The obtained data were reviewed and analyzed by the use of MedCal_version 17.9.7 (MedCalc Software bib, Ostend, Belgium). Numerical data were presented in the form of mean and standard deviation, while non-numerical data were presented as frequency and percentage. The difference between means was measured by t-test. Multiple regression analysis for estimation the efficacy of the measured sinuses dimensions in the prediction of the gender was performed.

\section{Results}

In the present study, male gender comprised slightly higher contribution in the study subjects. There was no significant difference in the gender distribution according to the age range (table 1).

The female gender showed smaller maxillary sinus CT dimensions (apart from width of the left sinus). However, the difference was non-significant (p>0.05) (tables 2\&3).

Multiple regression analysis for estimation of the efficacy of the measured sinuses dimensions in the prediction of the gender, revealed non-significant regression model (table 4), the coefficient of multiple determination ( $\mathrm{R}$ square) was 0.18 , which indicates poor discriminative power.

Table 1: Distribution of patients by age and gender.

\begin{tabular}{|c|c|c|c|c|}
\hline \multirow{2}{*}{ Age range (years) } & \multicolumn{2}{|c|}{ Female } & \multicolumn{2}{c|}{ Male } \\
\cline { 2 - 5 } & Number & \% & Number & 25 \\
\hline $\mathbf{2 0 - 4 0}$ & 16 & 25 & 16 & 15 \\
\hline $\mathbf{4 0 - 6 0}$ & 6 & 9.4 & 3 & 23.3 \\
\hline above 60 & 8 & 12.5 & 34 & 18.8 \\
\hline Total & 30 & 46.9 & 53.1 \\
\hline
\end{tabular}

Table 2: Left maxillary sinus CT dimensions in the study subjects according to gender distribution.

\begin{tabular}{|c|c|c|c|c|}
\hline & \multicolumn{4}{|c|}{ Left maxillary sinus dimensions (Mean \pm SD) } \\
\cline { 2 - 5 } & Length $(\mathrm{cm})$ & Width $(\mathrm{cm})$ & Depth $(\mathrm{cm})$ & Volume $\left(\mathrm{cm}^{3}\right)$ \\
\hline Male & $3.36 \pm 0.8$ & $2.42 \pm 0.47$ & $3.74 \pm 0.7$ & $16.16 \pm 5.8$ \\
\hline Female & $3.24 \pm 0.33$ & $2.49 \pm 0.4$ & $3.65 \pm 0.45$ & $15.92 \pm 4.8$ \\
\hline p value & $>0.05$ & $>0.05$ & $>0.05$ & $>0.05$ \\
\hline
\end{tabular}

Statistical analysis using T-test

$P<0.05$ : statistically significant, $P>0.05=$ statistically non-significant

Table 3: Right maxillary sinus CT dimensions in the study subjects according to gender distribution.

\begin{tabular}{|c|c|c|c|c|}
\hline & \multicolumn{4}{|c|}{ Right maxillary sinus dimensions (Mean \pm SD) } \\
\hline & Length $(\mathrm{cm})$ & Width $(\mathrm{cm})$ & Depth $(\mathrm{cm})$ & Volume $(\mathrm{cm} 3)$ \\
\hline Male & $3.4 \pm 0.81$ & $2.59 \pm 0.42$ & $3.87 \pm 0.72$ & $17.81 \pm 6.75$ \\
\hline Female & $3.25 \pm 0.42$ & $2.46 \pm 0.4$ & $3.68 \pm 0.51$ & $15.92 \pm 4.6$ \\
\hline p value & $>0.05$ & $>0.05$ & $>0.05$ & $>0.05$ \\
\hline
\end{tabular}

Statistical analysis using T-test

$P<0.05$ : statistically significant, $P>0.05=$ statistically non-significant

Table 4: Multiple regression analysis of the variable measures for the prediction of gender.

\begin{tabular}{|l|c|c|c|c|c|}
\hline & Parameter & Coefficients & S Error & t Stat & P-value \\
\hline \multirow{3}{*}{ Left sinus } & Intercept & 6.179297 & 2.608707 & 2.36872 & 0.02139 \\
\cline { 2 - 6 } & Max length & -0.00743 & 0.04069 & -0.18265 & 0.855742 \\
\cline { 2 - 6 } & Max width & -0.06311 & 0.05738 & -1.09977 & 0.276223 \\
\cline { 2 - 6 } & Max depth & -0.03175 & 0.05443 & -0.58323 & 0.562125 \\
\cline { 2 - 6 } & Volume & 0.000307 & 0.000833 & 0.368606 & 0.713837 \\
\hline \multirow{4}{*}{ Right sinus } & Max length & -0.05884 & 0.052795 & -1.11452 & 0.269903 \\
\cline { 2 - 6 } & Max width & -0.03861 & 0.079766 & -0.48405 & 0.63027 \\
\cline { 2 - 6 } & Max depth & -0.03557 & 0.076741 & -0.46345 & 0.644873 \\
\cline { 2 - 6 } & Volume & 0.000129 & 0.000114 & 1.128696 & 0.263926 \\
\hline
\end{tabular}




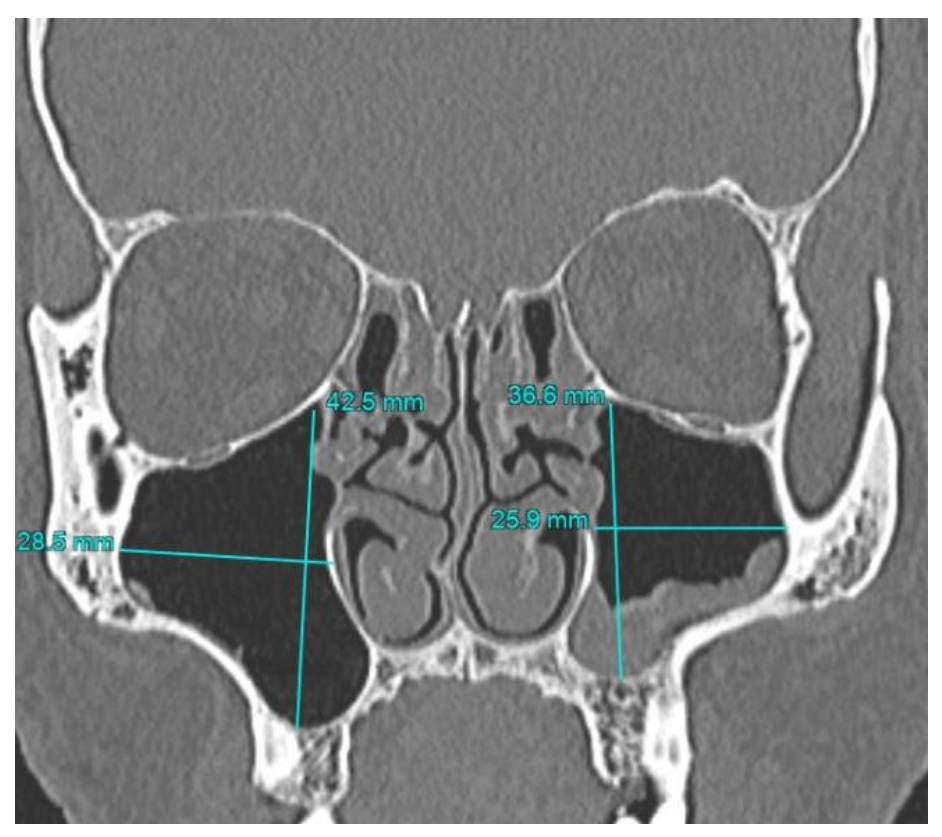

Figure 1: Maximum height and width of the maxillary sinus in coronal section.

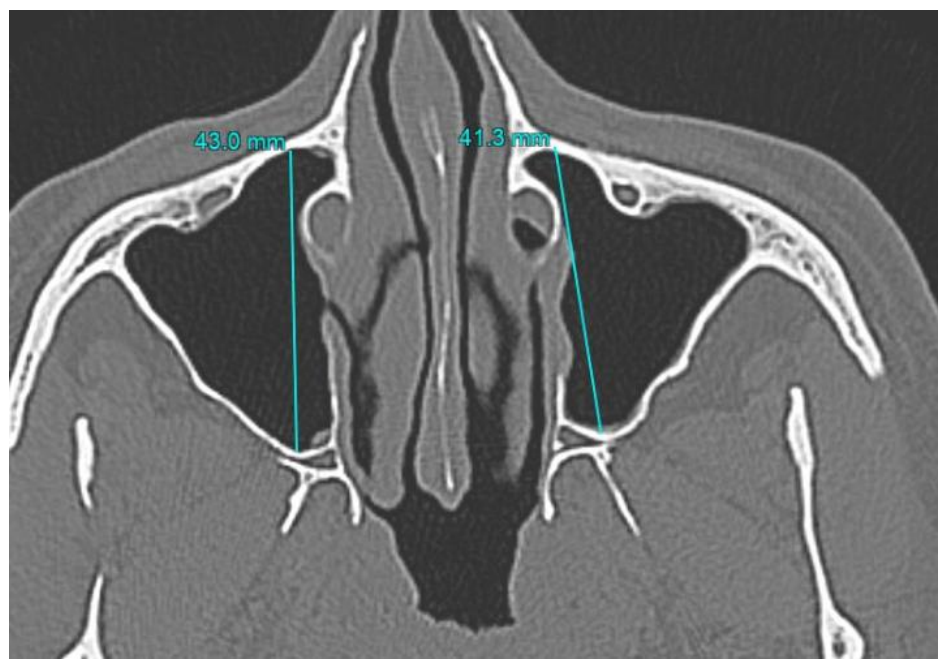

Figure 2: Maximum anterior posterior diameter of the maxillary sinus in coronal section.

\section{Discussion}

Gender identification is corner stone in the forensic medicine and it is a critical issue if no available data related to the deceased. Maxillary sinus pneumatization begins after birth and proceeds forwards till approximately the age of 20, the time of permanent teeth eruption. The gender difference in the maxillary sinus dimension was a matter of debate (Bangi et al., 2017). Considering this, the present study aimed at assessment of sinus dimensions as measured from CT scan and evaluate its potential efficacy in sex determination.

In the present study, the left maxillary sinus mean volume in males $\left(16.16 \mathrm{~cm}^{3}\right)$ was comparable to that found by Sharma et al.,(2014) $\left(16.4 \mathrm{~cm}^{3}\right)$, more than found by Karakas and Kavakli (2005) (13.09 $\mathrm{cm}^{3}$ ) and less than found by Johnson et al., (2011) $\left(18 \mathrm{~cm}^{3}\right)$,
Azhar et al., (2002) (30.4 $\left.\mathrm{cm}^{3}\right)$, Haleem et al., (2013) $\left(23.9 \mathrm{~cm}^{3}\right)$, and Samhitha et al., (2019) $\left(30.5 \mathrm{~cm}^{3}\right)$.

Regarding the female group, the left maxillary sinus mean volume $\left(15.92 \mathrm{~cm}^{3}\right)$ was comparable to that found by Johnson et al., (2011) $\left(15 \mathrm{~cm}^{3}\right)$, more than found by Sharma et al.,(2014) $\left(14.18 \mathrm{~cm}^{3}\right)$, and Karakas and Kavakli (2005) $\left(10.47 \mathrm{~cm}^{3}\right)$, and less than found by Azhar et al., (2002) (22.35 $\left.\mathrm{cm}^{3}\right)$, Haleem et al., (2013) (23.02 $\left.\mathrm{cm}^{3}\right)$, and Samhitha et al., (2019) $\left(26.7 \mathrm{~cm}^{3}\right)$.

While the right maxillary sinus mean volume in males in the present study $\left(17.81 \mathrm{~cm}^{3}\right)$ was comparable to that found by Johnson et al., (2011) $\left(18 \mathrm{~cm}^{3}\right)$, more than found by Karakas \& Kavakli (2005) (12.36 $\mathrm{cm}^{3}$ ) and Sharma et al.,(2014) $\left(15.8 \mathrm{~cm}^{3}\right)$, and less than found by Azhar et al., (2002) (30.34 $\left.\mathrm{cm}^{3}\right)$, Haleem et 
al., (2013) $\left(23.98 \mathrm{~cm}^{3}\right)$, and Samhitha et al., (2019) $\left(29.4 \mathrm{~cm}^{3}\right)$.

Regarding the right maxillary sinus mean volume in females $\left(15.92 \mathrm{~cm}^{3}\right)$ was more than found by Sharma et al., (2014) $\left(13.6 \mathrm{~cm}^{3}\right)$, and Karakas and Kavakli (2005) $\left(10.67 \mathrm{~cm}^{3}\right)$ and Johnson et al., (2011) $\left(14 \mathrm{~cm}^{3}\right)$, and less than found by Azhar et al., (2002) $\left(22.73 \mathrm{~cm}^{3}\right)$, Haleem et al., $(2013)\left(22.96 \mathrm{~cm}^{3}\right)$, and Samhitha et al., (2019) $\left(28.5 \mathrm{~cm}^{3}\right)$.

In the present study, the measurements of the maxillary sinus parameters (depth, anterior posterior diameter and width) in male and female groups showed higher values in males compared to females with statistically insignificant differences. As expected, the discriminative power for the sinus dimensions in determining gender was found to be poor (18\%).

The higher volume in male compared to female group was also reported by Samhitha et al., (2019), Teke et al., (2007), Sharma et al., (2014), Johnson et al., (2011), Azhar et al., (2002), Haleem et al., (2013), Karakas and Kavakli (2005) and Özdikici (2018), while it was against the reported finding by the study of Sheikh et al., (2018). The larger male sinus volume found in the present study could be explained by the documented male higher muscle mass, which should be supported by larger lungs and correspondingly larger airway as beginning from the nose, the maxillary sinus volume increases in turn (Samhitha et al., 2019). The different skeletal size between both genders also could attribute such finding (Sharan and Madjar, 2008).

The non-significant difference found in this study is in agreement with Sheikh et al., (2018), Samhitha et al., (2019), Saccucci et al., (2015) and Urooge and Patil (2017) studies. They conducted their studies to assess the possibility of gender identification by maxillary sinus dimensions means. They also did not find a significant difference between genders. On the other hand, other previous studies showed contradictory results, as Prabhat et al., (2016), Fernandes (2004) and Johnson et al., (2011) studies which reported the validity of maxillary sinus dimensions in the sex determination.

\section{Conclusion}

The present study did not validate the use of maxillary sinus dimensions in sex determination among Egyptian individuals.

\section{Limitations:}

The results of this study could not be generalized on the Egyptian population due to relatively small sample size; further studies with larger sample size are recommended.

\section{Conflict of Interest:}

None.

\section{References}

Akhlaghi M, Bakhtavar K, Kamali A, et al.,(2017): The diagnostic value of anthropometric indices of maxillary sinuses for sex determination using CT-scan images in Iranian adults: A crosssectional study. J Forensic Leg Med. 49:94-100.
Amin MF, and Hassan EI. (2012): Sex identification in Egyptian population using Multidetector Computed Tomography of the maxillary sinus. $J$ Forensic Leg Med. 19(2):65-9.

Azhar A, Ibrahim S, Salah M, et al.,(2002): CT scan images analysis of maxillary sinus dimensions as a forensic tool for sexual and racial detection in a sample of kurdish population. Eur Radiol. 12:1451-8.

Bangi BB, Ginjupally U, Nadendla LK, et al.,(2017): 3D Evaluation of Maxillary Sinus Using Computed Tomography: A Sexual Dimorphic Study. Int J Dent. 2017:9017078.

Fernandes CL (2004):. Forensic ethnic identification of crania: The role of the maxillary sinus - a new approach. Am J Forensic Med Pathol.25:30213.

Haleem H, and Al-Taei J (2013): Computed tomographic measurement of maxillary sinus volume and dimension in correlation to the age and gender (comparative study among individuals with dentate and edentulous maxilla). J Bagh College Dentistry. 25:1.

Johnson P, Jannert M, Stombeck A, et al.,(2011). Computed tomography measurements of different dimensions of maxillary and frontal sinuses. BMC Med Imaging. 11:1-8.

Karakas S, and Kavakli A (2005): Morphometric examination of paranasal sinuses and mastoid air cells using computed tomography. Ann Saudi Med.; 25:1-6.

Özdikici M (2018):Volumetric Evaluation of the Paranasal Sinuses with the Cavalieri Method. Anatomy Physiol Biochem Int J. 5(2): 555657.

Patil N, Karjodkar FR, Sontakke S, et al., (2012): Uniqueness of radiographic patterns of the frontal sinus for personal identification. Imaging Sci Dent. 42:213-7.

Prabhat M, Rai S, Kaur M, et al., (2016): Computed tomography based forensic gender determination by measuring the size and volume of the maxillary sinuses. J Forensic Dent Sci. $8: 40-6$.

Saccucci M, Cipriani F, Carderi S, et al., (2015): Gender assessment through three-dimensional analysis of maxillary sinuses by means of cone beam computed tomography. Eur Rev Med Pharmacol Sci. 19:185-93.

Samhitha G, Geethanjali B, Varsha M Ram P, et al., (2019): Measurements Of Maxillary Sinus In Correlation To Age And Gender By Computed Tomography. International Journal of Anatomy and Research. 7: 6732-6739.

Sharan A, and Madjar D (2008):Maxillary sinus pneumatization following extractions: a radiographic study. Int J Oral and Maxillofacial Implants. 23:48-56.

Sharma S, Massarat J, and Anil K (2014): Measurements of Maxillary sinus volume and dimensions by computed tomography scan for gender determination. $J$ journal of anatomical society of india. 63:36-42. 
Sheikh NN, Ashwinirani SR, Suragimath G, et al.,(2018): Evaluation of gender based on the size of maxillary sinus and frontal sinus using paranasal sinus views radiographs in Maharashtra population, India. J Oral Res Rev. 10:57-61.

Teke HY, Duran S, Canturk N, et al.,(2007): Determination of gender by measuring the size of the maxillary sinuses in computerized tomography scans. Surg Radiol Anat. 166:42-84

Urooge A, and Patil BA (2017): Sexual dimorphism of maxillary sinus: A morphometric analysis using cone beam computed tomography. J Clin Diagn Res. 11:ZC67-70.

\section{فعالية قياس أبعاد الجيوب الفكية بالتصوير المقطعي المحوسب في تحديد الجنس في عينة من المصريين}

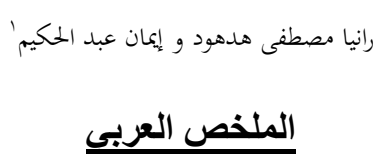

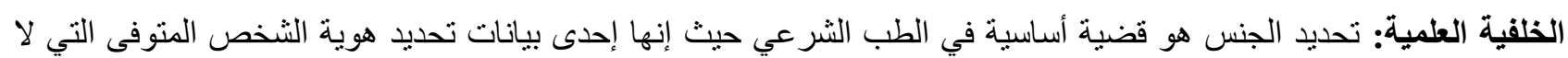

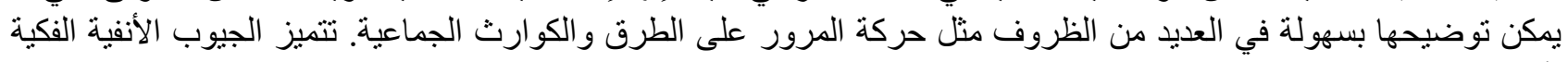
بأنها تظل سليمة حتى مع تشوه الجمجمة.

الهلف من الدراسة: تقييم أبعاد الجيوب الأنفية الفكية كما تم قياسها من الأشعة المقطعية وتقييم فعاليتها المحتملة في تحديد الجنس. المرضى وطرق الاراسة: حضر ع آ مريضا إلى قسم الأشعة بمستشفى الدمرداش ، جامعة عين شمس للتصوير المقطعي المحوسب للجيوب الأنفية و نم إجراء الأشعة المقطعية وقياس أبعاد الجيب الفكي. النتائج: لم يتم العثور على فروق ذات دلالة إحصائية بين الجنسين فيما يتعلق بأبعاد الجيب الفكي. الخلاصة: لم تثبت الدر اسة الحالية فعالية استخدام أبعاد الجيوب الأفية الفكية في تحديد جنس الأفر اد المصربين. 